Fertility, mortality, milk output, and body thermoregulation of growing $\mathrm{Hy}$-Plus rabbits fed on diets supplemented with multi-enzymes preparation

Hany M. Gado, Ahmed E. Kholif, Abdelfattah Z. M. Salem, Mona M. M. Elghandour, Oluwarotimi A. Olafadehan, Maricela A. Martinez, et

Tropical Animal Health and Production

ISSN 0049-4747

Volume 48

Number 7

Trop Anim Health Prod (2016) 48:1375-1380

DOI 10.1007/s11250-016-1095-5
Volume 48 - Number 7 · October 2016

\section{Tropical \\ Animal Health and Production}


Your article is protected by copyright and all rights are held exclusively by Springer Science +Business Media Dordrecht. This e-offprint is for personal use only and shall not be selfarchived in electronic repositories. If you wish to self-archive your article, please use the accepted manuscript version for posting on your own website. You may further deposit the accepted manuscript version in any repository, provided it is only made publicly available 12 months after official publication or later and provided acknowledgement is given to the original source of publication and a link is inserted to the published article on Springer's website. The link must be accompanied by the following text: "The final publication is available at link.springer.com". 


\title{
Fertility, mortality, milk output, and body thermoregulation of growing Hy-Plus rabbits fed on diets supplemented with multi-enzymes preparation
}

\author{
Hany M. Gado ${ }^{1}$ • Ahmed E. Kholif ${ }^{2} \cdot$ Abdelfattah Z. M. Salem $^{3}$ • Mona M. M. Elghandour ${ }^{3}$. \\ Oluwarotimi A. Olafadehan ${ }^{4}$ - Maricela A. Martinez ${ }^{5}$ - Ahmed Q. Al-Momani ${ }^{6}$
}

Received: 4 April 2016 / Accepted: 8 June 2016 / Published online: 18 June 2016

(C) Springer Science+Business Media Dordrecht 2016

\begin{abstract}
The aim of this study was to evaluate the fertility status, milk output, mortality, and body thermoregulation of rabbit does as affected by different levels of multi-enzyme extracts (EZ) in their diets. A total of 120 Hy-Plus rabbit does were divided into four comparable experimental groups ( $n=30$ does per group). Animals of each group were divided in six pens (five animals per pen), and each pen was used as an experimental unit. The first group was kept untreated and fed a commercial diet alone without enzyme extracts (EZ0), while the other groups were fed the same diet but supplemented with 1 (EZ1), 3 (EZ3), and 5 (EZ5) kg/ton of enzyme extracts, respectively. Feeding EZ additive increased $(P<0.05)$ conception and kindling rates, litter size and weight at birth, and litter size and bunny weight at weaning, with decreasing $(P<0.05)$ abortion rate. Moreover, total milk yield increased
\end{abstract}

Abdelfattah Z. M. Salem

asalem70@yahoo.com

1 Department of Animal Production, Faculty of Agriculture, Ain Shams University, Cairo, Egypt

2 Dairy Science Department, National Research Centre, 33 Bohouth St. Dokki, Giza, Egypt

3 Facultad de Medicina Veterinaria y Zootecnia, Universidad Autónoma del Estado de México, México, México

4 Department of Animal Science, University of Abuja, Abuja, Nigeria

5 Área Académica de Medicina Veterinaria y Zootecnia, Instituto de Ciencias Agropecuarias, Universidad Autónoma del Estado de Hidalgo, Rancho Universitario Av. Universidad Km 1 Ex-Hda de Aquetzalpa A.P. 32, 43600 Tulancingo, Mexico

6 Department of Animal Production and Protection, Faculty of Agriculture, Jerash University, Jerash 26150, Jordan
$(P<0.05)$ with increasing level of enzyme supplementation. Pre-weaning mortality decreased $(P<0.05)$ with EZ inclusion. Signs of vitality (rectal temperature, skin temperature, earlobe temperature, respiration rate, and pulse rate) were improved with EZ inclusion. For all results, $5 \mathrm{~kg}$ EZ/ton of feed was more effective than 1 and $3 \mathrm{~kg}$ EZ/ton feed. It can be concluded that supplementation of EZ in rabbit diet decreased mortality rate and enhanced fertility status and milk output.

Keywords Enzyme $\cdot$ Fertility $\cdot$ Milk output $\cdot$ Mortality · Rabbits

\section{Introduction}

Feed cost represents about $60-70 \%$ of rabbit keeping costs; therefore, maximizing utilization of nutrients is essential for the profitability and sustainability of rabbit production. Consequently, it has become very necessary to look for locally available, cheap, and nutritionally safe feed additives that would help to cut down production costs and improve production efficiency. Since the European Union banned most of the antibiotic growth promoters in animal nutrition due to cross and multiple resistances, much research has been conducted to explore the use of multi-enzymes as effective substitutes. Enzyme supplementation is meant to complement the endogenous enzymatic capability of animals and increase the nutritive value of feed (Abdel-Aziz et al. 2014, 2015). Recent studies have demonstrated that enzyme addition improves the feed utilization in the small intestine, changing the substrate that arrives at the hindgut. Such changes affect the development of the hindgut microbial population favoring the health status of the animals (Chesson and Steward 2001). The use of enzymes in animal feeds is becoming more common due to lower costs of commercial enzyme preparations, 
improved enzymes for animal feeds, and a better understanding of the composition of the anti-nutritive compounds (ElAdawy et al. 2013). Enzyme cocktails, more than one enzyme, often improve animal response compared to pure, single enzymes, assuming that cost considerations are not ignored. Several studies have attempted incorporation of exogenous enzymes into rabbit diets to improve nutrients availability; however, in most trials, rabbits appeared less responsive (ElSagheer and Hassanein 2014). The mode of action of enzymes on the different parts of rabbit gut was addressed by several researchers. Lafond et al. (2015) found that polysaccharide digestion was for $6 \mathrm{~h}$ along the digestive tract, using the gastrointestinal model 1 to mimic monogastric metabolism; moreover, their degradation appeared mainly at the jejunal level, and xylanases supplementation increased the amount of reducing end sugars in the jejuno-ileal dialysates. The enzyme extracts used, in the current study, are products containing cellulases, xylanases, $\alpha$-amylase, and proteases from an anaerobic bacterium and have shown a positive effect on nutrient utilization and performance of ruminant fed low-quality forages (Khattab et al. 2011). Therefore, the objective of the current experiment was to evaluate fertility status, mortality, milk output, and body thermoregulation of growing rabbits fed diets with multi-enzymes extracts as probiotics.

\section{Materials and methods}

\section{Experimental work}

A total of 120 Hy-Plus rabbit does in four comparable experimental groups ( $n=30$ ) were used to evaluate the effect of feeding different levels of multi-enzyme extracts (EZ) in diets. Each experimental group was divided into six pens (five animals per pen), and each pen was used as an experimental unit. The first group was kept untreated (control group -EZ0) and fed a commercial diet covering the nutritional requirements of different physiological status of rabbits, while the other three groups were fed the same diet but supplemented with 1 (EZ1), 3 (EZ3), and 5 (EZ5) kg multi-enzyme extracts per ton. The diet was formulated to contain $(\mathrm{g} / \mathrm{kg}$ dry matter (DM)) clover hay (300), wheat bran (262), soybean meal (160), molasses (30), limestone (10), $\mathrm{NaCl}$ (5), and vitamin-mineral premix (5). The following were contained in the vitamin-mineral premix per kilogram: vitamin A (10,000 IU), vitamin D3 (2000 IU), vitamin E (5000 IU), vitamin k (2 IU), vitamin B1 (2 IU), vitamin B4 (4 IU), vitamin B6 (3 IU), vitamin B12 (0.02 IU), biotin $(0.2 \mathrm{mg})$, choline $(1200 \mathrm{mg})$, niacin $(40 \mathrm{mg}), \mathrm{Zn}(60 \mathrm{mg}), \mathrm{Cu}$ (0.1 mg), Mn (62 mg), Fe (40 mg), folic acid (1 mg), and pantothenic acid $(15 \mathrm{mg})$. The diet contained $(\mathrm{g} / \mathrm{kg} \mathrm{DM})$ the following: crude protein 167 , ether extract 29.5 , crude fiber 131 , and digestible energy $10,400 \mathrm{KJ} / \mathrm{kg}$.
The enzyme cocktail was obtained from Ruminococcus flavefaciens and characterized for enzyme activities of endoglucanase, $\alpha$-amylase, protease, and xylanase in addition to the related anaerobic bacteria, which produced these enzymes, coated with starch and glycol. Enzyme activities in the enzyme preparation were determined for xylanase $(2.3 \mathrm{U} / \mathrm{g}), \alpha$-amylase $(61.5 \mathrm{U} / \mathrm{g})$, endoglucanase $(7.1 \mathrm{U} / \mathrm{g})$, and protease $(29.2 \mathrm{U} / \mathrm{g})$.

\section{Fertility and milk production experiment}

Rabbits of each treatment group were artificially inseminated using the corresponding experimental groups of rabbit bucks. The artificial insemination was carried out as described by Boiti et al. (2005). Palpation of all rabbit does was carried out 12 days post inseminating to determine pregnancy. At kindling, kindling rate, litter size, and weight at birth values were recorded. Pre-weaning mortality rates, bunny weight at weaning, and milk yield and composition per doe were estimated also during the suckling period. Milk yield was estimated after deprivation of the pups from suckling their mothers for $24 \mathrm{~h}$. After this, the pups were weighed before and after suckling, and the increase in pup's weight was taken as the milk yield.

\section{Body thermoregulation}

Body thermoregulation was estimated individually in the morning at $8.00 \mathrm{a}$ a.m. twice a week, during the experimental period. Both the does $(n=120)$ and the bucks $(n=192)$ were used for this experiment. Rectal temperature was measured by inserting a clinical thermometer in the rectum at a uniform depth of $1.5 \mathrm{~cm}$ for one minute. Skin temperature (between neck and loin, medial dorsal surface) was measured from one location on the body surface. The thermometer was fixed on the bare skin and fur, which was combed back into place by finger. Earlobe temperature was measured by a clinical thermometer, which was placed into direct contact with the central area of the auricle. Respiration rate was estimated by the frequency of the flank movements per minute. A hand counter was used to count the flank movement frequencies. Pulse rate was taken by putting the left hand on the left side of abdominal surface of the animal over the heart position and counting the pulse rates for $1 \mathrm{~min}$ by a hand counter.

\section{Statistical analyses}

Data were subjected to the analysis of variance using the general linear model program of SAS (2001). Data of each pen, used as an experimental unit, were analyzed using the following linear model:

$Y_{i j}=\mu+B_{i}+e_{i j}$ 
where $Y_{i j}=$ observation on $i$ th breed; $\mu=$ overall mean; $B_{i}=$ effect of $i$ th treated group ( $i=1$ to 4 ); and $e_{i j}=$ random error.

Percentage values were transformed to Arc-Sin values to approximate normal distribution before being statistically analyzed. Duncan's new multiple range tests were used to test the significance of the differences among means.

\section{Results}

Feeding enzyme additive at different levels did not affect $(P>0.05)$ bunny weight at birth and litter weight at weaning. On the contrary, feeding enzyme increased $(P<0.05)$ conception and kindling rates with increased effect as the enzyme level was increased. The abortion rate was decreased $(P<0.05)$ with feeding enzyme preparation. Moreover, compared to the control rabbits, litter size and weight at birth and litter size and bunny weight at weaning were improved $(P<0.05)$ with feeding enzyme additive, while higher values were observed with increasing enzyme additive levels (Table 1).

During the period from birth to weaning, mean milk yield increased $(P<0.05)$ with the increasing level of enzyme additive compared with the control treatment. Besides, total milk yield during nursing period had the same trend $(P<0.05)$ as mean milk yield (Table 2$)$. Pre-weaning mortality was decreased $(P<0.05)$ with addition of enzyme additive compared with control. Relative to the control treatment, the total preweaning mortality rate during suckling period decreased with feeding enzyme additive; moreover, values decreased with increasing enzyme additive levels (Table 2).
Compared with the control rabbits, rabbits receiving diets with enzyme additive supplementation had decreased $(P<0.05)$ means of rectal temperature, skin temperature, earlobe temperature, respiration rate, and pulse rate (Table 3).

\section{Discussion}

The present results are the second part of another experiment published by Seleem et al. (2014). The results of the published report used in the present discussion could be summarized as increased feed intake ( 2.8 to $8.5 \%$ ), increased daily weight gain (27.0 to $44.8 \%$ ), and improved feed conversion ratio (18.8 to $24.7 \%$ ). EZ5 had the best results followed by EZ3, then EZ1 and lastly EZ0 (control treatment). Blood parameters (e.g., total protein, albumin, and globulin) were improved with the inclusion of EZ in the diets of rabbits. Improved feed utilization with $\mathrm{EZ}$ additive inclusion revealed unaffected taste and smell of the fed diets, as suggested by El-Sagheer and Hassanein (2014).

Improved fertility status (e.g., abortion, conception and kindling rates, litter size and weight at birth and weaning, and bunny weight at birth and weaning) may be related to the improved nutritional status of the mother does. Moreover, EZ additive feeding decreased pre-weaning and total mortalities. The decreased mortality, improved fertility, and nutritional status of the mother does are the results of the stimulatory effect of nutrients made available to the animals, as the improved nutrition enhances productive status of does. Whereas numerous studies have been carried out with ruminants to investigate the potential benefits of feeding EZ (Rojo et al. 2015; Morsy et al. 2016), very few studies have been
Table 1 Fertility traits of rabbit does artificially inseminated by bucks as affected by enzyme additive to diets

\begin{tabular}{lllll}
\hline Items & \multicolumn{4}{l}{ Experimental groups $^{\mathrm{a}}$} \\
\cline { 2 - 5 } & EZ0 & EZ1 & EZ3 & EZ5 \\
\hline No. of inseminated does & 30 & 30 & 30 & 30 \\
No. of pregnant does & 17 & 21 & 26 & 27 \\
No. of kindled does & 16 & 20 & 26 & 27 \\
Abortion rate (\%) & $5.9 \mathrm{a} \pm 0.1$ & $4.8 \mathrm{a} \pm 0.02$ & $0.00 \mathrm{~b} \pm 0.0$ & $0.00 \mathrm{~b} \pm 0.0$ \\
Conception rate (\%) & $56.7 \mathrm{~d} \pm 1.3$ & $70.0 \mathrm{c} \pm 1.5$ & $86.7 \mathrm{~b} \pm 1.7$ & $90.0 \mathrm{a} \pm 2.2$ \\
Kindling rate (\%) & $53.3 \mathrm{~d} \pm 1.4$ & $66.7 \mathrm{c} \pm 1.1$ & $86.7 \mathrm{~b} \pm 1.5$ & $90.0 \mathrm{a} \pm 1.4$ \\
Litter size at birth (no.) & $6.9 \pm 0.9 \mathrm{~d}$ & $7.9 \pm 0.9 \mathrm{c}$ & $9.0 \pm 0.8 \mathrm{~b}$ & $9.89 \pm 0.8 \mathrm{a}$ \\
Litter weight at birth (g) & $276 \pm 19 \mathrm{c}$ & $318 \pm 22 \mathrm{~b}$ & $363 \pm 21 \mathrm{a}$ & $396 \pm 29 \mathrm{a}$ \\
Bunny weight at birth (g) & $40.0 \pm 2.8$ & $40.4 \pm 1.6$ & $40.5 \pm 1.8$ & $40.4 \pm 2.2$ \\
Litter size at weaning (no.) & $6.0 \pm 0.6 \mathrm{~d}$ & $7.1 \pm 0.5 \mathrm{c}$ & $8.3 \pm 0.4 \mathrm{~b}$ & $9.2 \pm 0.5 \mathrm{a}$ \\
Litter weight at weaning (g) & $4720 \pm 101$ & $5840 \pm 84$ & $7130 \pm 149$ & $8120 \pm 158$ \\
Bunny weight at weaning (g) & $788 \pm 15 \mathrm{c}$ & $822 \pm 16 \mathrm{~b}$ & $857 \pm 14 \mathrm{a}$ & $879 \pm 17 \mathrm{a}$ \\
\hline
\end{tabular}

Means bearing different letters within the same row are significantly $(P<0.05)$ different

${ }^{\text {a }}$ Diet supplemented with 0 (EZ0), 1 (EZ1), 3 (EZ3), and 5 (EZ5) kg enzyme/ton of diet 
Table 2 Milk yield and pre-weaning mortality rate of Hy-Plus rabbits as affected by enzyme additive to diets

\begin{tabular}{|c|c|c|c|c|c|}
\hline \multirow[t]{2}{*}{ Items } & \multirow{2}{*}{$\begin{array}{l}\text { Lactation periods (week) } \\
\text { Up to }\end{array}$} & \multicolumn{4}{|c|}{ Experimental groups $^{\mathrm{a}}$} \\
\hline & & EE0 & EE1 & EE3 & EE5 \\
\hline \multirow[t]{4}{*}{ Milk yield (g/doe) } & First week & $512 \pm 21 \mathrm{c}$ & $552 \pm 17 \mathrm{~b}$ & $599 \pm 21 \mathrm{a}$ & $622 \pm 21 \mathrm{a}$ \\
\hline & Second week & $706 \pm 24 c$ & $759 \pm 26 b$ & $829 \pm 37 a$ & $893 \pm 355 a$ \\
\hline & Third week & $843 \pm 42 c$ & $931 \pm 38 b$ & $1023 \pm 40 \mathrm{a}$ & $1102 \pm 44 a$ \\
\hline & Fourth week & $784 \pm 28 \mathrm{c}$ & $841 \pm 25 b$ & $885 \pm 25 a$ & $931 \pm 29 a$ \\
\hline \multicolumn{2}{|c|}{ Total milk yield during nursing period (g/doe) } & $2850 \pm 62 d$ & $3080 \pm 97 \mathrm{c}$ & $3340 \pm 102 b$ & $3550 \pm 108 \mathrm{a}$ \\
\hline \multirow[t]{4}{*}{ Pre-weaning mortality $(\%)$} & First week & $7.2 \pm 0.9 \mathrm{a}$ & $3.8 \pm 0.6 \mathrm{~b}$ & $3.0 \pm 0.2 \mathrm{c}$ & $2.7 \pm 0.3 \mathrm{c}$ \\
\hline & Second week & $3.92 \pm 0.23 \mathrm{a}$ & $2.63 \pm 0.26 b$ & $2.21 \pm 0.08 \mathrm{c}$ & $1.56 \pm 0.05 \mathrm{~d}$ \\
\hline & Third week & $2.04 \pm 0.04 \mathrm{a}$ & $2.03 \pm 0.05 \mathrm{a}$ & $1.36 \pm 0.03 b$ & $1.19 \pm 0.03 b$ \\
\hline & Fourth week & $1.04 \pm 0.16 \mathrm{a}$ & $1.38 \pm 0.14 \mathrm{a}$ & $0.92 \pm 0.01 b$ & $0.40 \pm 0.01 \mathrm{c}$ \\
\hline \multicolumn{2}{|c|}{ Total pre-weaning mortality rate during suckling period (\%) } & $13.5 \pm 1.3 \mathrm{a}$ & $9.5 \pm 1.0 \mathrm{~b}$ & $7.3 \pm 1.0 \mathrm{c}$ & $5.7 \pm 0.2 \mathrm{~d}$ \\
\hline
\end{tabular}

Means bearing different letters within the same row are significantly $(P<0.05)$ different

${ }^{\mathrm{a}}$ Diet supplemented with 0 (EZ0), 1 (EZ1), 3 (EZ3), and 5 (EZ5) kg enzyme complex/ton of diet

carried out on rabbits. However, EZ gained substantial interest in recent years in rabbit nutrition (Abdel-Aziz et al. 2015). Because the large intestine with cecum of the rabbit is a fermentation system similar to the rumen (De Blas and Wiseman 2010; Cunha and Cheeke 2012), some of our explanations would borrow from studies with ruminant animals. The direct results of such actions could have improved the nutrition status of rabbit does receiving the EZ preparation. Improved feed utilization as a result of EZ inclusion reported previously by Seleem et al. (2014) is due to improved digestion rate of fiber fractions and altered fermentation kinetics as well as improved synergism between exogenous and endogenous enzymes (Wang et al. 2001). Feeding EZ additive, in most cases, is paralleled with enhancing effect on microflora growth in gut and cecum and improving total and individual short chain fatty acids and nutrients (e.g., organic matter) digestibility. In the present study, the used EZ preparation contained protease amyloglucosidase xylanases, $\beta$-glucanase, cellulase, and hemicellulase.

The decreased mortality of rabbits fed EZ diets is another benefit of $\mathrm{EZ}$ additive inclusion. Feeding rabbits on $\mathrm{EZ}$ and balanced diets might help to control pre- and post-weaning
Table 3 Body thermoregulation response of rabbits (from weaning to adult age, $n=78$ ) as affected by enzyme in diets

\begin{tabular}{|c|c|c|c|c|c|}
\hline & & \multicolumn{4}{|c|}{ Experimental groups ${ }^{\mathrm{a}}$} \\
\hline & & EE0 & EE1 & EE3 & EE5 \\
\hline \multirow[t]{2}{*}{ Rectal temperature $\left({ }^{\circ} \mathrm{C}\right)$} & Males & $38.3 \pm 0.05$ & $38.1 \pm 0.05$ & $38.0 \pm 0.03$ & $38.0 \pm 0.03$ \\
\hline & Females & $38.4 \pm 0.04$ & $38.1 \pm 0.05$ & $38.0 \pm 0.04$ & $38.0 \pm 0.02$ \\
\hline Means $\pm \mathrm{SE}$ & & $38.4 \mathrm{a} \pm 0.01$ & $38.1 \mathrm{~b} \pm 0.01$ & $38.0 \mathrm{c} \pm 0.01$ & $38.0 \mathrm{c} \pm 0.01$ \\
\hline \multirow[t]{2}{*}{ Skin temperature $\left({ }^{\circ} \mathrm{C}\right)$} & Males & $37.5 \pm 0.03$ & $37.4 \pm 0.04$ & $37.3 \pm 0.02$ & $37.1 \pm 0.02$ \\
\hline & Females & $37.6 \pm 0.04$ & $37.4 \pm 0.03$ & $37.3 \pm 0.02$ & $37.2 \pm 0.02$ \\
\hline Means $\pm \mathrm{SE}$ & & $37.5 \mathrm{a} \pm 0.02$ & $37.4 b \pm 0.02$ & $37.3 c \pm 0.02$ & $37.2 \mathrm{~d} \pm 0.01$ \\
\hline \multirow[t]{2}{*}{ Earlobe temperature $\left({ }^{\circ} \mathrm{C}\right)$} & Males & $37.9 \pm 0.06$ & $37.6 \pm 0.04$ & $37.4 \pm 0.04$ & $37.2 \pm 0.05$ \\
\hline & Females & $38.0 \pm 0.04$ & $37.7 \pm 0.04$ & $37.4 \pm 0.05$ & $37.2 \pm 0.02$ \\
\hline Means $\pm \mathrm{SE}$ & & $38.0 \mathrm{a} \pm 0.03$ & $37.6 \mathrm{~b} \pm 0.03$ & $37.4 \mathrm{c} \pm 0.04$ & $37.2 \mathrm{~d} \pm 0.03$ \\
\hline \multirow[t]{2}{*}{ Respiration rate (rpm) } & Males & $132 \pm 6$ & $120 \pm 5$ & $113 \pm 5$ & $101 \pm 5$ \\
\hline & Females & $139 \pm 6$ & $124 \pm 6$ & $115 \pm 5$ & $110 \pm 5$ \\
\hline Means $\pm \mathrm{SE}$ & & $135 \mathrm{a} \pm 5$ & $122 b \pm 4$ & $114 b \pm 4$ & $106 c \pm 4$ \\
\hline \multirow[t]{2}{*}{ Pulse rate (ppm) } & Males & $243 \pm 10$ & $223 \pm 9$ & $216 \pm 6$ & $208 \pm 6$ \\
\hline & Females & $247 \pm 9$ & $230 \pm 7$ & $220 \pm 5$ & $210 \pm 7$ \\
\hline Means \pm SE & & $245 \mathrm{a} \pm 8$ & $227 b \pm 6$ & $218 b c \pm 5$ & $209 c \pm 5$ \\
\hline
\end{tabular}

Means bearing different letters within the same row are significantly $(P<0.05)$ different

${ }^{\mathrm{a}}$ Diet supplemented with 0 (EZ0), 1 (EZ1), 3 (EZ3), and 5 (EZ5) kg enzyme complex/ton of diet 
mortality by limiting pathogen microbial populations (GarcíaRuiz et al. 2006) or by reduction of $\mathrm{N}$ flow at ileum, as observed by García et al. (2005). In an agreement with the present results, Eiben et al. (2004) obtained improved performance and decreased mortality of weaned rabbits with the inclusion of cellulase in their diets.

Milk production improved with enzyme feeding and increased as the enzyme supplementation level increased. As previously shown in the improved fertility status, increased milk output can be explained based on the following factors: (1) increased intestinal metabolic activity, (2) modified intestinal hindgut microbiota by the exclusive competition with intestinal pathogenic bacteria, and (3) modified structure and function of the intestinal epithelium causing stimulated immune system (Malago and Koninkx 2011). Another important factor affecting milk output is the increased litter size. During the lactation, milk output is higher when the litter size is larger (McNitt and Lukefahr 1990). Increased feed intake and utilization are important reasons for increased milk output, as the milk produced by the doe is about 3 to $5 \%$ of the daily feed intake (Coudert et al. 1986).

Higher milk production and the nursing ability of the doe are key aspects for rearing young rabbits. Almost no published reports are available in the literature on the effect of EZ inclusion in diet of rabbits on milk production; therefore, the present results could not be compared. However, higher milk production of EZ supplemented groups may be due to increased availability of nutrients and energy for lactogenesis.

Enzyme additive feeding improved normal rabbit vital signs (e.g., rectal temperature, skin temperature, earlobe temperature, respiration rate, and pulse rate). The normal vital signs depend on recent activity, feed and water consumptions and the physiological stage of the rabbits. The measured physiological traits indicate physiological ability of rabbit body thermoregulation with feeding EZ additive. These results are due to the positive effects of EZ on the respiratory rate and body metabolism.

\section{Conclusions}

The exogenous multi-enzymes sourced from anaerobic bacteria and added to the total mixed rations of rabbits enhanced the fertility status, reproductive performance, and milk production and reduced the mortality rate of Hy-Plus rabbits. The $5 \mathrm{~kg}$ EZ/ton of feed was the best level compared to other levels (1 and $3 \mathrm{~kg}$ EZ/ton feed).

\section{Compliance with ethical standards}

Conflict of interest The authors declare that they have no conflict of interest.
Informed consent Consent was obtained from all participants included in the study.

\section{References}

Abdel-Aziz, N.A., El-Adawy, M.M., Salem, A.Z.M., Cerrillo-Soto, M.A., Camacho, L.M., Borhami, B.E., 2014. Effects of exogenous enzymes, Lactobacillus acidophilus or their combination on feed intake, digestibility and performance of rabbits fed sugarcane bagasse, Animal Nutrition and Feed Technology 14(1), 137-145.

Abdel-Aziz, N.A., El-Adawy, M., Mariezcurrena-Berasain, M.A., Salem, A.Z.M., Olivares-Pérez, J., Kholif, A.E. and Borhami, B.E., 2015. Effects of exogenous enzymes, Lactobacillus acidophilus or their combination on feed performance response and carcass characteristics of rabbits fed sugarcane bagasse, Journal of Integrative Agriculture, 14 (3), 544-549.

Boiti C., Castellini M., Thau-Clément M., Besenfelder U., Liguori L., Renieri T. and Pizzi F., 2005. Guidelines for the handling of rabbit bucks and semen, World Rabbit Science, 13, 71-91.

Chesson, A. and Steward, C.S., 2001. Modulation of the gut microflora by enzyme addition. In: A. Piva, K.E. Bach Knudsen and J.E. Lindberg (eds), Gut Environment of Pigs, (Nottingham University Press, Nottingham), pp. 165-179.

Coudert, P., Rouvier, R. and De Rochambeau, H., 1986. The Rabbit: Husbandry, Health and Production, Vol. 21, (Food and Agriculture Organization of the United Nation, Rome)

Cunha, T.J. and Cheeke, P.R., 2012. Rabbit Feeding and Nutrition, (Elsevier).

De Blas, C. and Wiseman, J., (eds) 2010. Nutrition of the Rabbit. CABI.

Eiben, C.S., Mézes, M., Zijártó, N., Kustos, K., Gódor-Surmann, K., Erdélyi, M., 2004. Dose-dependent effect of cellulase supplementation on performance of early-weaned rabbit. In Proceeding: 8th World Rabbit Congress, Puebla, México, 799-804. http://worldrabbit-science.com/WRSA-Proceedings/Congress-2004-Puebla /Papers/Feeding-\&-Nutrition/N-Eiben-1.pdf.

El-Adawy, M.M., Abou-Zeid, A.E., Camacho, L.M., Salem, A.Z.M., Cerrillo-Soto, M.A. and El-Rayes, T., 2013. Influence of jojoba meal treated with Lactobacillus acidophilus on digestibility, carcass traits and blood metabolites in growing rabbits, Animal Nutrition and Feed Technology, 13, 423-434.

El-Sagheer, M. and Hassanein, H.H.M., 2014. Effect of enzymes and probiotic mixture supplementation to the diet on performance and carcass criteria of growing females of three rabbit strains, Egyptian Poultry Science, 34, 273-288.

García, A.I., García, J., Corrent, E., Chamorro, S., García-Rebollar, P., De Blas, J.C., Carabaño, R., 2005. Effet de l'âge du lapin, de la source de protéineet de l'utilisation d'enzymessur les digestibilities apparentes de la matièresèche et de la protein brute sur un aliment lapin. In Proc.: 11èmes Journées de la Recherche Cunicole, Paris, France, 197-200. PMCid: PMC1201644.

García-Ruiz, A.I., García-Palomares, J., García-Rebollar, P., Chamorro, S., Caraba-O, R. and De Blas, J.C., 2006. Effect of protein source and enzyme supplementation on ileal protein digestibility and fattening performance in rabbits, Spanish Journal of Agricultural Research, 4, 297-303.

Khattab, H.M., Gado, H.M., Kholif, A.E., Mansour, A.M. and Kholif, A.M., 2011. The potential of feeding goats sun dried rumen contents with or without bacterial inoculums as replacement for berseem clover and the effects on milk production and animal health. International Journal of Dairy Science, 6, 267-277. 
Lafond, M., Bouza, B., Eyrichine, S., Rouffineau, F., Saulnier, L., Giardina, T., Bonnin, E. and Preynat, A., 2015. In vitro gastrointestinal digestion study of two wheat cultivars and evaluation of xylanase supplementation, Journal of Animal Science and Biotechnology, 6(1), 1-14.

Malago, J.J. and Koninkx, J.F., 2011. Probiotic-pathogen interactions and enteric cytoprotection. Probiotic Bacteria and Enteric Infections, (Springer Netherlands), pp. 289-311.

McNitt, J.I. and Lukefahr, S.D., 1990. Effect of breed, parity, day of lactation and number of kits on milk production of rabbits, Journal of Animal Science, 68(6), 1505-1512.

Morsy, T.A., Kholif, A.E., Kholif, S.M., Kholif, A.M., Sun, X. and Salem, A.Z.M., 2016. Effects of two enzyme feed additives on digestion and milk production in lactating Egyptian buffaloes, Annals of Animal Science, 16 (1), 209-222
Rojo, R., Kholif, A.E., Salem, A.Z.M., Elghandour, M.M.Y., Odongo, N.E., DE OCA, R.M., Rivero, N and Alonso, M.U., 2015. Influence of cellulase addition to dairy goat diets on digestion and fermentation, milk production and fatty acid content, The Journal of Agricultural Science, 153(08), 1514-1523.

SAS, 2001. Statistical Analysis System, User's Guide Version 8.2 Cary NC. USA.

Seleem, T.S.T., Zaki, T.G., El-Giziry, A.A. and Edrise, B.M., 2014. Effect of supplementing multi enzymes-probiotics weaning rabbit diets up on growing rabbit performance up to maturity age, Egyptian Journal of Nutrition and Feeds, 17(1), 63-74.

Wang, Y., McAllister, T.A., Rode, L.M., Beauchemin, K.A., Morgavi. D.P., Nsereko, V.L., Iwaasa, A.D. and Yang, W., 2001. Effects of an exogenous enzyme preparation on microbial protein synthesis, enzyme activity and attachment to feed in the rumen simulation technique (Rusitec), British Journal of Nutrition, 85,325-332. 